\title{
Dari Societeit Concordia Menuju Gedung Merdeka: Memori Kolektif Kemerdekaan Asia-Afrika
}

\author{
Achmad Sofyan \\ Program Studi S2 Ilmu Sejarah, Fakultas Ilmu Budaya, \\ Universitas Gadjah Mada
}

Alamat korespondensi: achmadsofyan819@gmail.com

Diterima/ Received:

9 Mei 2019

Disetujui / Accepted: 4 Juli 2019

\section{Abstract}

As a part of the cities in the colonization age, Bandung had a lot of colonial building. The buildings were Gemeente Huis, Gedung Sate, Bandung Technology Institute, Pasteur Institute, Societeit Concordia, and many others building. It can not be rejected that the colonial architecture always has a concept and meaning related to the structure when it builds. So that, the building had never extinct by the ages. Even though the function of buildings changed as public space, but it still had some memories and histories to remember. Based on that explanation, this paper has a purpose of describing the concept of cities of mind that introduced by Pierre Nora attached on a colonial building Societeit Concordia that led on the name changes as Gedung Merdeka because of political purpose in a declaration of independence by the nation of Asia-Afrika at Bandung. This article is used as the historical method. It analyzes the meaning changes that happened on collective memory after the changes on the name of Gedung Merdeka building.

Keywords: Societeit Concordia; Sites of Memory; Merdeka Building; Asia-Afrika Conference; Collective Memory.

\begin{abstract}
Abstrak
Sebagai bagian dari kota kolonial pada zamannya, Bandung memiliki banyak bangunan kolonial. Bangunan kolonial tersebut antara lain Gemeente Huis, Gedung Sate, Institut Teknologi Bandung, Pasteur Institut, Societeit Concordia, dan beberapa bangunan lainnya. Tidak dapat dipungkiri bahwa arsitektur kolonial selalu terkait konsep dan makna yang melatarbelakangi pembangunanya. Oleh sebab itu, wajar jika bangunan kolonial di Bandung tidak lekang oleh zaman. Meskipun sudah beralih fungsi sebagai ruang publik, namun bangunan-bangunan seperti disebutkan di atas tetap memiliki kenangan dan ingatan di dalamnya. Berdasar penjelasan tersebut, tulisan ini bertujuan untuk menggambarkan bagaimana sebuah konsep sites of memory yang dikenalkan Pierre Nora ada dalam salah satu bangunan kolonial, Societeit Concordia yang berubah nama menjadi Gedung Merdeka karena peristiwa politik kemerdekaan bangsa Asia-Afrika di Bandung. Kajian ini menggunakan metode sejarah untuk menganalisis makna nama bangunan. Perubahan makna bangunan merupakan usaha untuk menegaskan identitas kedaulatan Indonesia yang tidak dapat ditawar kembali.
\end{abstract}

Kata Kunci: Societeit Concordia; Sites of Memory; Gedung Merdeka; Konferensi Asia Afrika; Memori Kolektif. 


\section{Pendahuluan}

Berbicara tentang kota Bandung, dapat dilihat bagaimana sebuah kota kolonial yang berkembang cukup pesat. Dalam perjalanannya, Bandung setara dengan Batavia, Semarang, Malang, dan Surabaya sebagai kota kolonial di Hindia Belanda. Dengan panorama yang indah, serta udaranya yang sejuk, menjadi alasan Bandung dijadikan sebagai salah satu pusat pemerintahan (Priangan), serta pendidikan (Asmawi, et al., 1985, p. 7). Salah satu faktor yang kemudian memperkuat identitas Bandung sebagai pusat pemerintahan Hindia Belanda, dapat kita lihat dari arsitektur bangunanbangunan bercorak kolonial yang berdiri dengan megah di kota Bandung, seperti: Gemeente Huis, Gedung Sate, Institut Teknologi Bandung (ITB), Pasteur Institut, kawasan Braga, Villa Isola, kawasan pemukiman Dago, dan beberapa gedung bercorak kolonial lain yang tersebar di Bandung.

Bangunan-bangunan besar tersebut merupakan masterpiece pemerintahan kolonial Belanda di kota Bandung. Konstruksi bangunan yang ditata sedemikian rupa dan indah menjadikan tata letak kota Bandung pada masa kolonial sangat teratur dan modern. Setiap detail objek bangunan pada masa kolonial memiliki arti dan pemaknaan tersendiri. Objek yang terkesan kecil dan tidak bermakna sebenarnya menjadi sangat penting apabila kita mengetahui konsep dan makna yang melatarbelakanginya. Hal inilah yang membuat arsitektur bangunan kolonial tidak lekang oleh zaman, dan sangat relevan dengan pernyataan Konrad Smigliesky, yaitu "City without memory is like a man without memory" yang dikutip Nahrul Ulum (Ulum, 2017, p. B 212).

Sebagai salah satu kota kolonial yang banyak memiliki bangunan arsitektur bercorak kolonial, Pemerintah kota Bandung kemudian melakukan berbagai cara untuk "menjaga ingatan masa lalu" (Pawitro, 2015, p. A 17). Upaya konservasi pun dilakukan, dengan menjadikan gedung-gedung sebagai bangunan cagar budaya dan museum. Usaha itu tidak lain adalah langkah yang ditempuh pemerintah kota Bandung untuk menghadirkan bangunan (gedung) sebagai sarana edukasi, terutama bagi generasi muda. Berdasar latar belakang di atas, essai ini berfokus pada pemaknaan Gedung sebagai sebuah sites memory atau sebuah peristiwa yang menghasilkan memori kolektif untuk masyarakat. Adapun pembahasan difokuskan pada Gedung Merdeka, atau yang dahulu bernama Societeit Concordia,

Sites of Memory merupakan titik temu dalam sejarah dan memori. Sites of Memory digunakan sebagai penanda akan ingatan masa lalu tetapi tetap berada dalam jalur penelitian sejarah (Budiawan, ed, 2013). hal inilah yang menjadi kerangka awal penelitian bagaimana sebuah sites of memory yang tergambar dalam bangunan kolonial sebagai sebuah memori dapat dilengkapi dengan narasi sejarah yang menyertainya. Di Indonesia sendiri, kajian antara sejarah dan memori belum begitu banyak berkembang serta diminati oleh para peneliti. Sejarah dan memori pada awalnya memiliki pemahaman yang berbeda. Sepert digambarkan Pierre Nora yang dikutip Budiman dalam buku sejarah dan memori: titik simpang dan titik temu. Norra berpendapat bahwa memori itu menubuh pada individu atau sekelompok orang (embodied), sedangkan sejarah itu menempel (embedded) (Budiawan, ed, 2013, p. x). Hal 
lain yang membuat perbedaan dari kedua hal tersebut ialah memori dipandang sebagai sesuatu yang spontan serta naluriah, sehingga tidak bisa dipercaya keabsahannya. Sementara itu, sejarah bersifat rasional dengan cara melakukan pembuktian metodologinya dalam penulisan (Budiawan, ed., 2013, p.xi).

Untuk membuktikan bagaimana sites of memory bisa menjadi jembatan antara sejarah dan memori dalam satu bagian yang utuh, tulisan ini akan menggunakan metodologi sejarah. Sumber primer (foto dan koran digital) dan sumber sekunder (melalui buku dan artikel berita) yang memuat pembahasan terkait dengan perjalanan Societeit Concordia yang memiliki perubahan pemaknaan secara kolektif bagi masyarakat Bandung secara khusus dan Indonesia dengan lingkup lebih luas digunakan untuk menyusun artikel ini

Beberapa penelitian sebelumnya yang menunjang penyelesaian kajian ini. Kajian yang dilakukan oleh Nurgiansyah dan Falah (2017) membahas mengenai fungsi Gedung Merdeka sebagai obyek wisata, belum bergerak pada sisi historis kenapa Gedung Merdeka bisa dijadikan sebagai objek wisata. Sementara itu, kumpulan essay mengenai sejarah dan memori dengan yang dieditori oleh Budiawan (2015) menggambarkan bagaimana sites of memory dapat diciptakan. Dengan meminjam beberapa permasalahan yang sama mengenai konsep sites of memori. Buku ini menjadi rujukan awal penulisan artikel ini. Selanjutnya, kajian yang dilakukan oleh Katam (2014) memberikan argumentasi alasan dan proses perubahan Bandung dari ibu kota bagian kerajaan menjadi ibu kota kolonial Hindia Belanda dengan melakukan pembangunan penunjang pemerintahan. Terakhir, kajian dari Utama (2017) berkontribusi dalam pengayaan informasi latar peristiwa Konferensi Asia-Afrika di Bandung yang justru belum banyak membahas Gedung Merdeka sebagai tempat pelaksanaannya.

Secara garis besar perubahan pemaknaan yang akan dibahas dalam tulisan ini dilandasi dengan perubahan nama gedung Societeit Concordia pada tahun 1879 sampai dengan pergantian nama menjadi Gedung Merdeka pada tahun 1955. Dalam menguraikan perubahan pemaknaan nama gedung tersebut, dalam tulisan ini dibahas juga pembangunan kota Bandung masa awal untuk memperkuat penggambaran pembangunan gedung Societeit Concordia.

Tahun 1879 dijadikan sebagai titik awal kajian karena melihat pada pembangunan gedung Societeit Concordia sebagai bangunan dengan ciri khas kolonialisme yang sangat kental. Sementara itu, tahun 1955 digunakan sebagai akhir dari periode penulisan. Karena pada tahun inilah perubahan nama gedung dilakukan. Perubahan nama tersebut, ternyata memiliki tujuan untuk mengubahmemori kolektif kolonialisme yang selama ini melekat.

Kajian ini bertujuan untuk melengkapi penulisan sejarah Bandung yang sudah ada sebelumnya, seperti Gemeente Huis karya Sudarsono Katam yang membahas pembangunan kota Bandung sebagai kota kolonial. Selain itu, untuk melengkapi penulisan sejarah dan memori yang masih sangat jarang diminati oleh peneliti Indonesia. Dengan harapan bahwa banyak peristiwa yang termaktub dalam momen hingga kemudian bisa kita kenang dengan monumen. 


\section{Metode}

Penelitian ini dilakukan dengan metode sejarah yang terdiri dari pencarian sumber sejarah (heuristik) yang didapatkan dari buku, artikel, dan koran yang menunjang penelitian, verifikasi (kritik sumber), interpretasi, dan diakhiri dengan penulisan sejarah (historiografi). Kemudian untuk menunjang penelitian sejarah dan memori, digunakan pendekatan kerangka teoretis sites of memory yang dikembangkan ilmuwan sosial Prancis seperti Halbswach, Pierre Norra dan lainnya. Kerangka teoretis Sites of Memory sangat penting digunakan untuk lebih memperjelas bagaimana suatu perubahan memori kolektif masyarakat bisa diciptakan oleh kuasa individu.

\section{Batasan Memori Kolektif}

Memori dan ingatan akan terus ada, dirasakan oleh setiap individu atau kelompok dalam memaknai suatu peristiwa yang terjadi, baik peristiwa yang menyenangkan maupun peristiwa yang menyedihkan. Sebagai contoh, memori dan ingatan korban kekerasan dan pemerkosaan pasti menjadi sebuah memori yang tidak menyenangkan. Contoh lainnya adalah seseorang yang sedang dilanda perasaan bahagia akan mencoba mengingat apa yang sedang terjadi. Hal ini membuktikan bahwa proses melupakan dan mengingat merupakan sebuah proses alami manusia. Lantas, apakah manusia perlu menciptakan atau melakukan suatu hal sebagai bagian dari proses mengingat dan melupakan? Pertanyaannya kemudian adalah apakah memori dan ingatan manusia memiliki suatu studi tersendiri, terutama untuk menjelaskan proses mengingat dan melupakan?

Studi memori sendiri memiliki keterkaitan dengan sejarah, setidaknya hal inilah yang coba digambarkan Budiawan (2013) yang berbicara tentang memori dan sejarah. Kita juga harus melihat wacana sosial yang dibangun oleh Maurice Halbswach, sosiolog Prancis yang mengenalkan konsep memori kolektif. Halbswach menyatakan bahwa setiap orang memiliki ingatan individu dan kelompok. Oleh sebab itu, interaksi sosial yang terjadi antara individu dengan anggota kelompoknya menentukan bagaimana seseorang mengingat pengalaman dari masa lalu dan apa yang diingatnya (Russel, 2006, p. 796).

Gagasan Halbswach mengenai memori dan sejarah ini kemudian dilanjutkan oleh Pierre Nora. Nora sendiri memulai gagasannya dengan konsep embodied dan embedded. Apa yang dimaksud Nora tentang embodied adalah memori yang bersifat menubuh pada individu atau sekelompok orang, sedangkan embedded cenderung dekat dengan sejarah sebagai bagian yang menempel pada seseorang atau pun sekelompok orang. Maka dari itu, perbedaan antara memori, dan sejarah ada pada titik ini. Memori sebagai embodied tidak mudah berubah menjadi disembodied, dan sejarah sebagai embedded sangat rentan berubah menjadi disembedded, bahkan memiliki kans untuk menyubordinasikan memori. Penyubordinasian inilah yang disebut Nora sebagai sites of memory, yaitu penanda ingatan masa lalu sebagai sebuah memori, tetapi tetap dalam kuasa sejarah. Hal ini berarti memori tidak lagi bersifat spontan, tetapi menjadi salah satu bagian dari duty of remember (Budiawan, 2013). 
Selain itu, pembahasan juga ditekankan pada fungsi gedung yang pada masa kolonial merupakan ruang publik, serta digunakan sebagai sarana hiburan bagi masyarakat, sementara di masa sekarang menjadi sarana wisata pendidikan. Gedung sebagai ruang publik tentu memiliki kenangan dan makna dalam perjalananya. Pierre Nora dalam artikel Between Memory and History: Les Lieux de Memoire menyatakan bahwa situs memori (Lieux de memoire) merupakan sebuah kristalisasi memori atas sesuatu yang terjadi di masa lalu (Nora, 1989). Lebih lanjut Noora menjelaskan bahwa Lieux de memoire atau yang sering kali disebut dengan sites of memory merupakan alat untuk mengingat sebuah peristiwa. Sites of Memory tidak terbentuk secara spontan dan memang harus dibentuk secara sengaja untuk melanggengkan ingatan yang terkandung. Sites of memory sendiri dapat berupa arsip, monumen, museum, pemakaman, festival, hari perayaan, perjanjian, dan tempat suci (Nora, 1989, p. 12). Untuk menciptakan sebuah memori kolektif, konsep Sites of memory Pierre Nora dapat memainkan peranan sebagai pengingat atau bahkan sebagai tindakan untuk melupakan sebuah peristiwa sejarah (Budiawan, ed., 2013, p. 34).

\section{Bandung: Kota Kolonial dan Bangunan yang Menyertainya}

Dipati Ukur dan Tatar Ukur merupakan dua kata yang sangat melekat dengan kota Bandung. Dipati Ukur sendiri merupakan adipati di wilayah Tatar Ukur yang dalam perkembangannya berubah menjadi Bandung (Lasmiyati, 2016, p. 382). Wilayah Tatar Ukur berada di bawah Kerajaan Sumedanglarang, sebuah wilayah yang ingin mengembalikan kejayaan Kerajaan Sunda sejak 1580. Wilayah Tatar Ukur sendiri mengalami beberapa kali pergantian kekuasaan, mulai dari Kerajaan Sumedanglarang, kemudian Kesultanan Cirebon, hingga pada akhirnya jatuh ke dalam kekuasaan Kerajaan Mataram pada 1620. Pada saat itulah dikenal wilayah Priangan yang sebelumnya bernama Sumedanglarang. Priangan kemudian diambil alih oleh Vereenigde Oost Indische Compagnie(VOC) pada 1705. Namun demikian, setelah VOC mengalami kebangkrutan pada 1799, wilayah Priangan diserahkan kepada Pemerintah Kolonial Belanda (Katam, 2014, p. 9).

Penyerahan wilayah kepada Pemerintah Kolonial Belanda tentu menjadi babak baru bagi perjalanan Tatar Ukur. Harus diakui bahwa hal itu merupakan bagian dari sejarah panjang perjalanan kota Bandung, sampai akhirnya berkembang menjadi kota kolonial. Perkembangan awal Bandung sebagai sebuah kota kolonial dimulai ketika proyek pembangunan jalan raya pos (Groote Postweg) yang menghubungkan Anyer sampai dengan Panarukan oleh Gubernur Herman William Daendels sebagai upaya strategi perang mempertahankan Jawa dari serangan Inggris. Melihat pembangunan jalan yang melewati daerahnya tersebut, Bupati Tatar Ukur R.A Wiranatakoesoema merasa bahwa harus ada perpindahan ibu kota Tatar Ukur yang sebelumnya berada di daerah Krapyak agar segera dipindahkan lebih dekat dengan Groote Postweg (Katam, 2014, p. 13). Menurut R.A Wiranatakoesoema, perpindahan ibu kota ini akan memudahkan masyarakat terlibat dalam kegiatan perdagangan dan kegiatan perekonomian lainnya. Hal ini dinilai cukup menguntungkan karena wilayahnya tentu akan terdampak kegiatan ekonomi secara langsung. Atas pertimbangan 
tersebut, melalui sebuah besluit (surat keputusan), pada 25 September 1810, Kota Bandung didirikan dan dinyatakan sebagai ibu kota Kabupaten Bandong (Katam, 2014, p. 13).

Perpindahan dan penempatan Bandung sebagai sebuah ibu kota ternyata mendapat respons yang sangat baik dari penduduk Eropa yang ada di Hindia Belanda, terutama para pekerja dan pemilik perkebunan yang datang dan menetap di Bandung. Mereka yang datang dan menetap tentu harus beradaptasi dengan kondisi tropis Bandung dan membentuk persepsi ${ }^{1}$ lingkungan ideal yang akan mempermudah proses adaptasi mereka di tanah perantauan. Lingkungan ideal itu mereka wujudkan ke dalam pembangunan infrastruktur dan gedung-gedung yang terdiri atas gedung pemerintahan, jalan beraspal, lampu penerangan jalan, taman kota, gedung perkantoran, gedung olahraga, gedung pendidikan dan hiburan. Gedung-gedung itu umumnya dibangun sesuai dengan kondisi lingkungan tempat tinggal mereka di Belanda.

Pembangunan secara pesat inilah yang menjadikan Bandung sebagai salah satu kota penting di Hindia Belanda. Letaknya yang strategis menjadikan status Bandung meningkat dari ibu kota kabupaten menjadi ibu kota keresidenan, yaitu Keresidenan Priangan. Selain mengalami peningkatan status, Bandung juga kemudian menjadi Gemeente (kota), Stadsgemeente (kota besar), dan diproyeksikan menjadi ibu kota Hindia Belanda (Hermawan, 2012, p. 2). Gemeente Huis (Balaikota Bandung) merupakan salah satu bangunan bercorak kolonial yang berfungsi sebagai gedung pemerintahan kolonial. Pembangunan Gemeente Huis Bandung tidak lepas dari kontribusi Andries de Wilde, seorang pemilik perkebunan kopi yang menjabat sebagai Asisten Residen Bandung. Andries de Wilde menggunakan sebagian besar lahan perkebunan kopinya untuk dibangun gedung pemerintahan yang baru (Katam, 2014, p. 26). Gedung ini merupakan hasil karya Ir. E. H. de Roo. Ia adalah seorang arsitektur Belanda yang mendapatkan pengaruh dari arsitektur Amerika Serikat yang bernama Frank Lloyd Wright. De Roo terkenal dengan konsep rancangan atap yang kuat berbahan sirap serta memiliki kemiringan yang landai (Katam, 2014, p. 28). Beberapa bangunan lain yang juga merupakan karya de Roo ialah Gedung Sate di Bandung.

Selain dihiasi oleh karya Ir. E. H. de Roo, Bandung juga berkembang dengan bangunan kolonial hasil karya Schoemaker bersaudara. Mereka adalah R. L. A. Schoemaker dan C. P. Schoemaker. Beberapa bangunan yang merupakan rancangan R. L. A. Schoemaker antara lain Paleies van Leger Commandant (Gedung Markas Komando, Militer III/Siliwangi di Jalan Aceh), Gedung Departement van Oorlog / Departemen Peperangan (Detasemen Markas Kodam III/Siliwangi di Jalan Kalimantan). Sementara itu, sang Kakak, C. P. Schoemaker yang merupakan guru arsitektur Soekarno berhasil membangun Hotel Panghegar, Gedung Merdeka, Vila Isola (Bumi Siliwangi), dan gedung Boscha di Lembang (Suganda, 2015, p. 32). Ia terkenal dengan konsep arsitek konservatif yang berusaha merancang bangunan yang

1Pandangan mereka terkait kawasan tempat tinggal dan perkantoran 
menjadi trade mark Bandung sehingga tidak salah jika ia dijuluki sebagai sang penanda landmark Bandung (Suganda, 2015, p. 33).

\section{Gedung Societeit Concordia: Sebuah Memori Kolonialisme}

Penduduk Eropa berbondong-bondong menempati Bandung sebagai kota yang baru dibangun karena menjanjikan kehidupan yang lebih baik dari segi ekonomi dan keamanan. Perpindahan ini melibatkan banyak elemen penduduk Eropa mulai dari pemilik perkebunan, pegawai pemerintahan, sampai dengan pekerja perkebunan kemudian membentuk sebuah pemukiman baru. Mereka umumnya tinggal secara terpisah dengan penduduk lokal kota Bandung. Selayaknya penduduk Eropa di kota lain, hiburan menjadi salah satu sarana melepas lelah dan penat ketika selesai bekerja. Mereka kemudian membentuk sebuah perkumpulan untuk menghibur diri mereka sendiri. Salah satu perkumpulan yang terkenal pada waktu itu adalah Societeit Concordia. Adapun anggota Societeit Concordia terdiri atas perkumpulan penduduk Belanda yang bekerja di perkebunan. Mereka membentuk Societeit Concordia pada 1879. Societeit Concordia sendiri berasal dari bahasa Belanda, yaitu Societeit yang memiliki arti "Balai" dan Concordia dari bahasa latin yang berarti "Kesepakatan" (Oesman dan Oesman, 2016, p. 15).

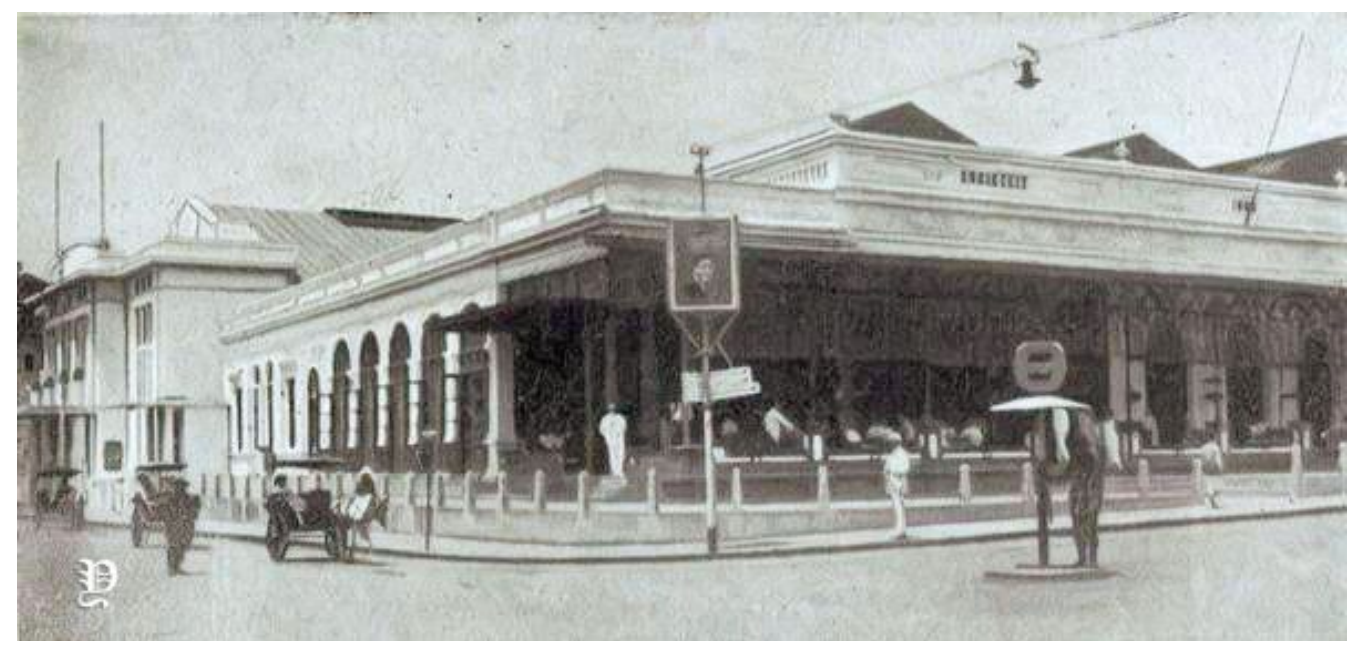

Gambar 1. Societeit Concordia 1920 - 1930

Sumber: pinterest.com, diakses pada 2 Juli 2019.

Dalam salah satu artikel online disebutkan bahwa jumlah anggota dari perkumpulan ini pada awalnya18 orang (Historia, 23 Februari 2015). Mereka membeli sebuah bangunan di tepi jalan Groote Postweg, yang pada awalnya tidak lebih dari sebuah bangunan bekas kedai kopi yang tidak terlalu besar. Namun kemudian, perkembangan perkumpulan yang semakin banyak memaksa mereka membangun gedung baru pada 1895. Perkumpulan ini membeli sebuah bangunan megah di Jalan Braga (Historia, 23 Februari 2015). Societeit Concordia sendiri berisi hiburan kelas atas bagi penduduk kolonial Eropa di kota Bandung. Setiap akhir pekan, gedung ini selalu ramai dengan pertunjukan musik, sandiwara, dan dansa. Selain mengadakan 
pertunjukan rutin, mereka juga menyelenggarakan pertunjukan khusus yang bertajuk Bragabal (berisi pertunjukan tarian dan musik) sekali dalam tiga bulan. Pergantian tahun juga menjadi momen spesial bagi penduduk Eropa di Bandung. Mereka merayakan pergantian tahun dengan mengadakan pesta yang dikunjungi oleh khalayak ramai (penduduk Eropa). Oleh sebab itu, tidak heran jika Societeit Concordia berkembang mejadi Societeit terbaik di Hindia Belanda (Historia, 23 Februari 2015).

Namun kemudian, kenyataan yang sebenarnya terjadi adalah perkembangan Societeit Concordia semakin menjadi contoh tentang adanya jurang pemisah antara penduduk Eropa dan masyarakat pribumi terlihat jelas. Hal ini terjadi karena pada 1921, bangunan concordia kembali dirombak menjadi gedung pertemuan yang lebih megah. Fasilitas gedung benar-benar dilengkapi sejalan dengan semakin besarnya kebutuhan akan hiburan bagi penduduk Eropa di Bandung. Perombakan ini melibatkan C.P Wolff Schoemaker (Historia, 23 Februari 2015). Ia merombak Concordia menggunakan gaya Art Deco² dengan menambah pilar-pilar besar di pintu masuk. Perombakan lainnya terjadi pada 1940. Pada waktu itu, Concordia kembali dirombak dengan gaya internasional oleh A. F. Aalbers. Aalbers membuat lengkungan yang memberikan kesan tidak kaku terhadap gedung tersebut. Fungsi gedung pun bertambah. Tidak hanya terbatas pada ruang pertemuan untuk pertunjukan kesenian, melainkan juga tempat rekreasi keluarga (Pikiran Rakyat, 6 Februari 2018). Pada akhirnya, Societeit Concordia berubah menjadi kawasan yang benar-benar megah, dan tentunya tidak dapat diakses oleh masyarakat pribumi.

\section{Dari Societeit Concordia ke Gedung Merdeka: Memori Nasionalisme Politik Global}

Pasca-Perang Dunia II, dunia terbelah menjadi dua bagian secara politik global. Hal ini terjadi karena perebutan pengaruh antara kapitalisme yang dikomandoi oleh Amerika Serikat, dan komunisme yang dipimpin oleh Uni Soviet. Perebutan pengaruh tersebut membuat dunia terpecah menjadi dua bagian yang kemudian dikenal dengan istilah Blok Barat dan Blok Timur. Perluasan perebutan pengaruh tersebut tidak hanya terjadi di Eropa dan Amerika saja, tetapi juga meluas hingga ke Asia dan Afrika. Sebagai negara yang baru saja mendapatkan kemerdekaan pada 1945 dan memperoleh kedaulatan empat tahun setelahnya, yakni pada 1949, Indonesia tidak ingin terlibat ke dalam dua pusaran kekuatan tersebut (Barat dan Timur), sebab Sukarno menilai hal itu sebagai penjajahan model baru yang dikenal dengan Neoliberalisme dan Neokolonialisme. Berdasar pertimbangan itu, Sukarno menghimbau negara-negara di Asia dan Afrika agar tidak terlibat dalam arus penjajahan model baru tersebut.

Berdasar hal tersebut, Indonesia pada 1955 menyelenggarakan sebuah konferensi tingkat global yang kemudian dikenal dengan Konferensi Asia Afrika. Pemilihan Bandung sebagai tuan rumah Konferensi Asia Afrika tidak terlepas dari kesepakatan lima perdana menteri dalam Konferensi Bogor. Kelima perdana menteri

\footnotetext{
${ }^{2}$ Art Deco adalah gaya arsitektur yang berkembang pada periode 1920-an. Thomas Karsten adalah salah satu arsitek yang mengenalkan gaya Art Deco
} 
tersebut adalah Ali Sastroamidjojo (Indonesia), Muhammad Ali (Pakistan), Pandit Jawaharlal Nehru (India), Sir John Kotelawala (Srilanka), dan U Nu (Myanmar/ Burma). Kelimanya juga sepakat bahwa Konferensi Asia Afrika diadakan pada akhir April 1955.

Persiapan penyelenggaraan Konferensi Asia Afrika mulai dilakukan. Bandung dipilih menjadi tempat penyelenggaraan. Pemilihan Bandung sebagai tempat berlangsungnya Konferensi Asia Afrika sendiri merupakan permintaan langsung dari Presiden Sukarno (Detiknews, 13 April 2015). Dalam buku 50 Tahun Indonesia dan Konferensi Asia Afrika yang dikutip oleh artikel detik online. Sukarno menyatakan bahwa pemilihan tersebut lebih didasarkan pada alasan yang cenderung bersifat emosional karena Bandung merupakan awal mula gerakan kemerdekaan yang dipimpinnya secara langsung (Detiknews, 13 April 2015). Pemilihan yang cenderung bersifat emosional ini melibatkan seluruh memori dari Sukarno akan kota Bandung. Dalam buku Jejak Sukarno di Bandung I (1921-1934), Her Suganda menyatakan bahwa kota Bandung memiliki sisi sejarah yang sangat penting untuk Sukarno muda, sebab di kota Bandung lah Sukarno melanjutkan pendidikan selepas lulus Hogare Burlijke School (HBS) di Surabaya. Sukarno melanjutkan pendidikan sebagai arsitek di Technische Hogeschool (TH) atau yang sekarang kita kenal dengan ITB (Suganda, 2015).

Di Bandung pula, Sukarno memutuskan mengambil jalur politik untuk merebut kemerdekaan dari kolonialisme Belanda. Setelah lulus dari Technische Hogeschool (TH). Sukarno bergiat dalam politik dengan mendirikan perkumpulan Algemene Studie Club dan pada 27 Juli 1927 sekaligus menjadi pimpinannya (Suganda, 2015 : 63). Keputusan terjun ke dunia politik menjadikan Sukarno sebagai salah satu tokoh yang diawasi oleh Pemerintah Kolonial Belanda. Sampai akhirnya, Bandung juga lah yang menjadi pengalaman pertama Sukarno merasakan jeruji besi, yaitu di penjara Banceuy bersama dengan teman-teman Partai Nasional Indonesia (PNI) lain yang ditangkap di Yogyakarta (Suganda, 2015).

Perlawanan politik Sukarno tidak berhenti dengan penahanan di penjara Banceuy. Pada Desember 1930, dalam pengadilan Landraad di Bandung, Sukarno sekali lagi melakukan perlawanan dengan pidato $p l e d o i^{3}$ yang terkenal dengan istilah "Indonesia Menggugat". Pidato pembelaan yang menjadi pedoman politik menentang Imperialisme Belanda tersebut memantik pejuang lain yang dengan sengaja datang untuk melihat sidang pembelaan Sukarno (Suganda, 2015, p. 105). Risalah "Mentjapai Indonesia Merdeka" yang dimuat dalam Fikiran Ra'jat (Pikiran Rakyat) mungkin menjadi karya terakhir Sukarno di Bandung. Risalah ini tidak berbeda jauh dengan pidato pembelaan di pengadilan Landraad. Sukarno menentang imperialisme lama dan baru yang melakukan eksploitasi sumber daya alam Indonesia sehingga menyebabkan malapetaka bagi penduduk pribumi. Demikian beberapa peristiwa di Bandung yang dinilai meninggalkan kesan di benak Sukarno (Suganda, 2015).

\footnotetext{
3 Pidato pembelaan Sukarno.
} 
Sementara itu, persiapan Konferensi Asia Afrika dimulai dengan menentukan gedung yang akan digunakan sebagai tempat pelaksanaan. Mengenai hal ini, Utama (2017) mengutip pernyataan Ali Sastroamidjojo yang menyatakan bahwa terdapat permasalahan terkait pemilihan gedung. Menurut Ali Sastroamidjojo, walaupun Bandung berkembang sebagai kota kolonial, tetapi tidak banyak bangunan besar yang dapat menampung perwakilan negara yang berpartisipasi dalam Konferensi Asia Afrika (Utama, 2017 , p. 94). Kalau pun ada, itu sudah dapat dipastikan digunakan sebagai kantor pemerintahan. Pada akhirnya, disepakati Gedung Societeit Concordia dan Gedung Dwi Warna sebagai tempat pelaksanaan Konferensi Asia Afrika. Gedung Merdeka digunakan sebagai pleno dan pertemuan terbuka, sementara Gedung Dwi Warna digunakan pada sesi komite tertutup. Selain kedua tempat tersebut, Pemerintah Indonesia juga menggunakan Hotel Savoy Homann, Astoria, dan Grand Hotel Preanger sebagai tempat menginap perwakilan delegasi Konferensi Asia-Afrika (Utama, 2017).

Pemilihan Societeit Concordia sebagai tempat penyelenggaraan Konferensi Asia Afrika tidak terlepas dari peran Sukarno sebagai seorang arsitektur. Walaupun pada saat dipilih gedung Concordia mengalami kerusakan yang hebat karena sudah lama ditinggalkan dan pernah dibakar pada masa revolusi, pada kenyataannya gedung ini tetap dipilih karena gedung ini memiliki ruang pertunjukan yang besar sehingga mampu menampung semua perwakilan dari negara Asia Afrika. Persiapan Konferensi Asia Afrika dijalankan. Konferensi Asia Afrika menceritakan adanya perang dingin yang terjadi antara Sukarno dan Ali Sastroamidjojo tentang penataan arsitektonis Gedung Societeit Concordia yang akan digunakan untuk sidang pleno (Anwar, 2009, p. 121).

Situasi perang dingin antara Sukarno dan Ali Sastroamidjojo juga digambarkan oleh Shimazu (2012) yang mengutip Roeslan Abdulgani dalam Bandung Connection. Berikut kutipan percakapan di antara kedua pemimpin negara ini.
“Bung Karno berbicara terhadap saya, apa yang anda tahu atau Ali tentang arsitektur? Saya seorang insyinyur teknik sipil dan saya mengetahui semua seluk beluk arsitektur. Bagian dalam gedung Concordia harus menginspirasi. Setiap orang yang duduk di dalamnya harus diilhami, jangan menjadikan gedung ini membosankan, jangan terlalu kaku seperti ruang pengadilan. Itulah yang Ali ketahui sebagai ahli hukum (pengacara). Anda tahu yang saya pikirkan? Seorang pengacara tidak akan pernah memulai revolusi. Mereka tidak memiliki inspirasi. Padahal para peserta harus direngkuh dalam inspirasi. Untuk alasan itu, ubah interior gedung ini dengan apa yang saya katakan (Shimizu, $2013: 241$ ).

Selain terjadi perang dingin pada persiapan Konferensi Asia Afrika, dalam inspeksi mendadak yang dilakukan oleh Sukarno tepat sebelas hari sebelum pelaksanaan, Sukarno juga mengganti nama Gedung Societeit Concordia menjadi Gedung Merdeka (Nurgiansyah dan Falah, 2017, p. 133). Perubahan nama ini mendapatkan kecaman dari Pemerintah Kota Bandung. Hal itu karena Sukarno diketahui tidak berkomunikasi dengan pemerintah kota sebelum mengganti nama 
gedung. Namun demikian, Sukarno tetaplah Sukarno. Ia memiliki satu alasan mengapa perubahan nama gedung itu harus dilakukan. Sukarno beralasan bahwa pergantian nama Gedung Societeit Concordia menjadi Gedung Merdeka merupakan bentuk memori kolektif masyarakat Indonesia dan masyarakat dunia yang menandai ada peristiwa penting yang di dalamnya adalah usaha memperjuangkan kemerdekaan bangsa di Asia Afrika dari belenggu kolonialisme. Peristiwa penting itu terjadi di dalam sebuah gedung yang pada awalnya merupakan simbol kolonialisme di kota Bandung. Gedung megah itu, tidak lain adalah Societeit Concordia.

Pada akhirnya, Konferensi Asia Afrika yang diselenggarakan pada 18-24 April 1955 merupakan sebuah pencapaian diplomasi yang sangat besar bagi Indonesia di mata dunia. Hal ini diperkuat dengan respons dunia internasional yang beragam. Amerika,Inggris, dan negara blok Barat lainnya melihat bahwa ada kecenderungan netralitas dari negara peserta Konferensi Asia Afrika terkait persinggungan antara blok Barat dan Timur. Amerika melihat bahwa jika negara yang terlibat Konferensi Asia Afrika tidak memihak blok Barat, maka sudah pasti negara tersebut menjadi musuhnya (Utama, 2017 : 144). Berbeda dari respons Uni Soviet yang melihat bahwa upaya yang dilakukan dalam Konferensi Asia Afrika dapat menciptakan perdamaian, persahabatan, dan saling perhatian antarsesama negara peserta (Utama, 2017 ; 147). Selain respons tersebut, nyatanya menurut Shimizu (2014) pelaksanaan Konferensi Asia Afrika yang terjadi pada masa pemerintahan Perdana Menteri Ali Sastroamidjojo dianggap sebagai prosesi yang monumental setelah periode kemerdekaan 1945 (Shimizu, 2013). Bahkan pidato Bung Karno pada 18 April 1955 dengan judul Let a New Asia and a New Africa be Born yang dilakukan selama 40 menit dan tanpa teks adalah awal dari kemunculan tatanan baru dunia ketiga, yaitu kelompok dunia yang tidak terlibat ke dalam Blok Barat dan Timur (Karyono, 2012).

\section{Simpulan}

Perubahan nama Gedung Societeit Concordia menjadi Gedung Merdeka merupakan sebuah usaha untuk menegaskan kepada dunia mengenai kedaulatan Indonesia yang tidak dapat ditawar lagi. Ingatan kolektif tentang pembangunan Societeit Concordia merupakan warisan kolonialisme dengan citra sebagai gedung pertemuan super mewah. Ingatan ini coba digantikan dengan memori pelaksanaan Konferensi Asia Afrika yang menjadi simbol kemerdekaan bagi negara Asia Afrika yang masih terbelenggu kolonialisme pada saat itu. Dengan kata lain, ada upaya menghilangkan memori kolonialisme yang terbentuk dalam Societeit Concordia menjadi memori nasionalisme tingkat global pascapenyelenggaraan Konferensi Asia Afrika pada 1955. Peringatan dan perayaan Konferensi Asia Afrika yang dilakukan pada 24 April 1980 menjadi salah satu hasil dari proses mengubah ingatan terhadap sites of memory tersebut. Pada peringatan itu juga, Gedung Merdeka diresmikan oleh presiden Soeharto sebagai sebuah museum, yaitu Museum Konferensi Asia Afrika. Peresmian Gedung Merdeka sebagai museum, memberi dampak yang lebih besar lagi, yaitu bahwa ingatan memori kolektif masyarakat Indonesia cenderung lebih melihat Gedung Merdeka sebagai simbol kemerdekaan negara Asia Afrika. 
Peresmian Museum Konferensi Asia Afrika merupakan gagasan dari Mochtar Kusumaatmadja yang menjabat sebagai Menteri Luar Negeri Republik Indonesia. Pada saat melakukan kunjungan ke negara-negara lain, termasuk negara Asia dan Afrika, banyak pemimpin negara di Asia dan Afrika menanyakan kondisi Gedung Merdeka dan Bandung yang mereka kenal sebagai Ibu kota Asia Afrika. Dengan pernyataan tersebut, Sukarno berhasil mengubah ingatan memori kolektif untuk masyarakat Indonesia sendiri dan masyarakat luar negeri. "Keangkuhan" Gedung Societeit Concordia sebagai bagian dari kolonialisme rupanya dapat berganti menjadi "bangunan kemerdekaan" bernama Gedung Merdeka.

\section{Referensi}

Anwar, Rosihan (2009). Sejarah kecil petite histoire Indonesia. Jakarta : Kompas.

Asmawi, Bakran (2009). Pesan pembaharuan dari Bandung. Jakarta : LKBN ANTARA.

Budiawan, ed. (2015). Sejarah dan memori: Titik simpang dan titik temu. Yogyakarta: Ombak.

Detik News, 13 April 2015, https://news.detik.com/berita/2885811/ini-alasan-bungkarno-pilih-bandung-untuk-konferensi-asia-afrika/2.

Historia, 23 Februari 2015, https://historia.id/modern/articles/berpesta-di-braga61W1P.

Karyono, Tri (2012). “Arsitektur Dunia Ketiga”. Dalam Sinar Harapan 27 April 2012. Katam, Sudarsono (2014). Gemeente huis. Bandung: Kiblat Buku Utama.

Nora, P. (1989). Between and History: Les Lieux de Memoire. Representation. No. 26: 7-24.

Nurgiansyah, N. F. dan Falah, Miftahul (2017). Gedung Merdeka sebagai objek wisata di Kota Bandung. Patanjala, 9 (1): 127-142

Lasmiyati, L. (2016). Dipati ukur dan jejak peninggalannya di Kecamatan Ciparay Kabupaten Bandung (1627-1633). Petanjala, 8(3): 381-396.

Oesman, Yevis M., Oesman, I. F. (2016) Pandangan masyarakat Kota Bandung terhadap bangunan cagar budaya. Strategic: Jurnal Pendidikan Manajemen Bisnis, 16(6): 15-20.

Pawitro, U. (2015). 'Preservasi - Konservasi Bangunan Bersejarah dan Pengelolaan Kawasan Kota Lama'. Simposium Nasional RAPI XIV : A13-A20

Pikiran Rakyat, 6 Februari 2018, http://www.pikiran-rakyat.com/bandungraya/2018/02/06/gedung-merdeka-dahulu-menghadap-ke-jalan-braga-418956.

Russell, Nicolas (2006). Collective Memory before and after Halbwachs. The French Review, 79 (4) : 792-804.

Shimizu, Naoko (2014). Diplomacy as theatre : Staging the Bandung Conference of 1955. Modern Asia Studies, 48 (1): 225-252

Suganda, Her (2015). Jejak Soekarno di Bandung (1921-1934). Jakarta : Kompas.

Ulum, Nahrul (2017). 'Ragam Ornamentasi Pada Fasad Bangunan Kolonial di Jalan Groote Postweg, Bandung'. Prosiding Seminar Heritage IPLBI : B 211-218.

Utama, Wildan (2017). Konferensi Asia-Afrika 1955: Asal usul intelektual dan warisannya bagi gerakan global anti imperialism. Tangerang : Marjin Kiri. 